\title{
Seasonal Variation Of Heavy Metals In Sediment And Water Of Lagos Lagoon
}

\author{
*Oshisanya, K.I ${ }^{1}$., Unyimadu J.P ${ }^{2}$.,Shelle R.O.D ${ }^{3}$., Nubi O.A4., Ladigbolu, I.A. ${ }^{5}$, Oguguah N.M. ${ }^{6}$, Olumodeji,O.O. ${ }^{7}$, \\ Adeleye A.O. ${ }^{8}$, Fashade, A.O ${ }^{9}$. \\ ${ }^{1-9}$ DEPARTMENT OF PHYSICAL AND CHEMICAL OCEANOGRAPHY \\ NIGERIAN INSTITUTE FOR OCEANOGRAPHY AND MARINE RESEARCH
}

\author{
VICTORIA ISLAND LAGOS, NIGERIA. \\ E-mail: kharphioshi@yahoo.com Phone: +2348035031722
}

\begin{abstract}
The concentration of Chromium (Cr), Lead ( $\mathrm{Pb})$, Zinc $(\mathrm{Zn})$, Cadmium $(\mathrm{Cd})$ and physicochemical parameters were determined in Surface water and Sediment at different stations in Lagos lagoon during the wet season. The result showed that the concentration of $\mathrm{Cr} 0.039 \mathrm{mg} / 1, \mathrm{~Pb} 0.043 \mathrm{mg} / \mathrm{l}, \mathrm{Zn} 0.107 \mathrm{mg} / \mathrm{l}, \mathrm{Cd} 0.17 \mathrm{mg} / 1$ in surface water were generally low when compared to WHO standard "2004. The concentration of Zn in the water is within the limits permitted by the Lagos State Environmental Protection Agency (LASEPA) of $1.0 \mathrm{mg} / \mathrm{L} \mathrm{Zn} \mathrm{set} \mathrm{for}$ water. The mean levels of heavy metals in the sediment of Lagos lagoon were generally low and fell within the acceptable limits described by WHO,2004 and FEPA.The average concentration for the heavy metals were $\mathrm{Cr}$ $0.046 \mathrm{mg} / \mathrm{g}, \mathrm{Pb} 0.054 \mathrm{mg} / \mathrm{g}, \mathrm{Zn} 0.730 \mathrm{mg} / \mathrm{g}, \mathrm{Cd} 0.523 \mathrm{mg} / \mathrm{g}$ respectively. Comparism of these values with that of the surface water indicates that most metals were adsorbed to the sediment. None of the trace metals investigated were above the maximum permissible level set by world health organization (WHO). For the physicochemistry the salinity ranged from $0.0 \%$ to $3.1 \%$ indicating a typical freshwater condition, higher dissolved oxygen were also recorded this may be due to run-off during the wet season.

[Oshisanya, K.I., Unyimadu J.P., Shelle R.O.D., Nubi A.O, Ladigbolu, I.A., Oguguah N.M., Olumodeji,O.O., Adeleye A.O., Fashade, A.O. Seasonal Variation Of Heavy Metals In Sediment And Water Of Lagos Lagoon. Journal of American Science 2011; 7(3):384-387]. (ISSN: 1545-1003). http://www.americanscience.org.
\end{abstract}

Key words: Sediment, heavy metals, Surface Water, Lagos Lagoon.

\section{INTRODUCTION}

The Lagos Lagoon complex is the largest lagoon systems of the Gulf of Guinea coast in West Africa (Hill and Webb, 1958).In Nigeria over $85 \%$ of all industries are situated in Lagos metropolitan area and their effluents ultimately get into the Lagos Lagoon complex directly or indirectly via drainages or streams and pollute the nursery grounds of both fishes and shrimps (Oyewo, 1998).

There is an increasing concern regarding the roles and fates of heavy metals in Nigerian environment. Much of this concern arises from the low level of available information on the concentration of these metals within the environment. The contamination of seafood by heavy metals is a potential problem to man. Human may be contaminated by organic and inorganic

Pollutants associated to aquatic systems by consumption of contaminated fish and other aquatic foods from this environment, aquatic organisms accumulate metals to concentrations many times higher than present in water. The rate of heavy metal pollutants into natural waters in Nigeria is still largely unknown (Oyewo, 1998).

Heavy metals are vital source of pollution not just because they are toxic above a relatively low concentration but also because they are persistent, remaining in the environment long after the source of pollution has been removed (Voutsinou-Taliadouri, 1981).Contamination with heavy metals may have devastating effects on the ecological balance of the aquatic environment and the diversity of aquatic organisms becomes limited.

Basics of samples of water, sediment and biota from Lagos lagoon is due to many renown scientist such as Ajao, Okoye et al. had researched this lagoon and came up with the fact that the lagoon is continuously under the effect of pollution by industries around the city.

The aim of this study is to determine the Level of heavy metals in water and sediment in different stations of Lagos lagoon. This study becomes 
imperative, not only because of the threat of heavy metals to public water supplies, but also the damage caused to the aquatic life (Canli et al, 1998).

\section{MATERIALS AND METHOD}

\section{Study Area}

Lagos Lagoon lies between longitudes 30 22'E and 30 40'E and latitude $6017^{\prime} \mathrm{N}$ and 60 28 'N.The lagoon is generally shallow with a depth of between 0.3 and $3.2 \mathrm{~m}$ in most parts with the exception of some dredged parts, notably in the Lagos Harbour,where depth is greater than $10 \mathrm{~m}$.

\section{Collection of water and Sediment sample}

Surface water samples from the selected locations were collected by dipping plastic containers of $1.5 \mathrm{ml}$ to about $6-10 \mathrm{~cm}$ below the surface film.

Some analysis were done in-situ while the plastic containers were well corked, labeled and carried to the laboratory where it was stored in a refrigerator before the commencement of further analysis.

The sediment was collected with the aid of a grab and stored in a polythene bag.

\section{Chemical Analysis of Samples.}

Temperature was determined using mercury in glass thermometer calibrated in degree centigrade $\left({ }^{\circ} \mathrm{C}\right)$. The surface water temperature was measured on site. $\mathrm{Ph}$, Salinity, Turbidity and Conductivity were measured in-situ using Horiba water checker model U10.

The Dissolved oxygen was determined by Winkler's titrimetric method and Alkalinity was estimated titrimetrically using $0.02 \mathrm{Hcl}$ with methyl orange as indicator.

Chromium $(\mathrm{Cr})$, Lead $(\mathrm{Pb})$, Zinc $(\mathrm{Zn})$ and Cadmium (Cd) in the samples was assayed using Atomic Absorption Spectrophotometer (AAS) model standards were prepared from $1000 \mathrm{mg} / \mathrm{l}$ stock solution of the metals of interest.

Serial dilutions were made to obtain 1.0, 2.0 and $3.0 \mathrm{mg} / \mathrm{l}$.The equipment was calibrated using deionized water as blank.

\section{RESULT AND DISCUSSION}

The Concentration of the heavy metals determined in the surface water and sediment is indicated in Figure 1 and 2, while the physicochemical parameters are in figure 3 .
The mean levels of heavy metals in the sediment of Lagos lagoon results showed that the concentration of the metals were generally low and fell within the acceptable limits described by FEPA 1998 and WHO, the average concentrations are $\mathrm{Cr}$ $0.046 \mathrm{mg} / \mathrm{kg}, \quad \mathrm{Pb} 0.054 \mathrm{mg} / \mathrm{kg}, \quad \mathrm{Zn} 0.730 \mathrm{mg} / \mathrm{g}, \quad \mathrm{Cd}$ $0.523 \mathrm{mg} / \mathrm{kg}$, the mean levels in surface water is generally low when compared to WHO standard 2004. The metal levels in sediments were higher than those in the lagoon surface water and animals are known to take up and accumulate heavy metals from contaminated soils Madejon,et al, 2003.

Although levels of Cd (0.173), Cr (0.039), Pb $(0.043) \mathrm{mg} / \mathrm{g}$, were within the normal range in minimum allowable in diet of man however, continual consumption could lead to accumulation to with adverse health implications since $\mathrm{Cd}$ has been linked to renal diseases and cancer Kjellstroem, T., 1986. Zn showed the highest mean relative to other metals and this result can be deduced to conform to the expected since $\mathrm{Zn}$ forms part of trace metal required by the body for healthy functioning.

The highest salinity recorded was $3.1 \%$ in Iddo, most stations recorded zero salinity indicating a fresh water condition, Ajayi, S.O, Osibanjo, O (1981). The DO recorded at all stations were high and above the WHO standard (Table 3 ) this could be attributed to flood water dilution. The highest $\mathrm{PH}$ was 9.1 and the water samples were Turbid during the period of study, the particulate matters brought into the lagoon by surface run-off and flood must have been responsible for the high turbidity recorded in the wet season.

Lagos lagoon has been subjected to contaminating materials, capable of initiating the impairment of the water quality.

\section{CONCLUSION}

The metal levels in sediment were higher than those in the Lagoon surface water and this confirms that sediments are important hosts for toxic metals. The occurrence of enhanced concentrations of heavy metals in coastal sediment such as that obtained in Lagos lagoon can be a good indication of man induced pollution rather than by natural enrichment through geological weathering.

Metals from Lagoon surface water could be a contributing source to the levels in animal's hence continual assessment is highly essential. 


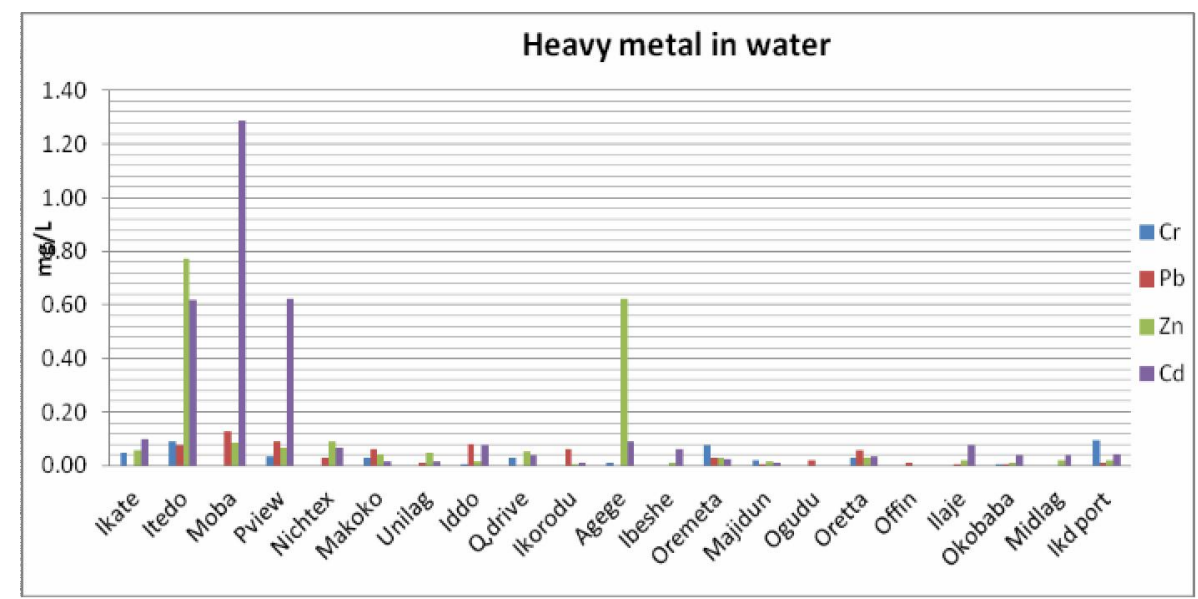

Figure 1. Distribution of heavy metals in Surface water.

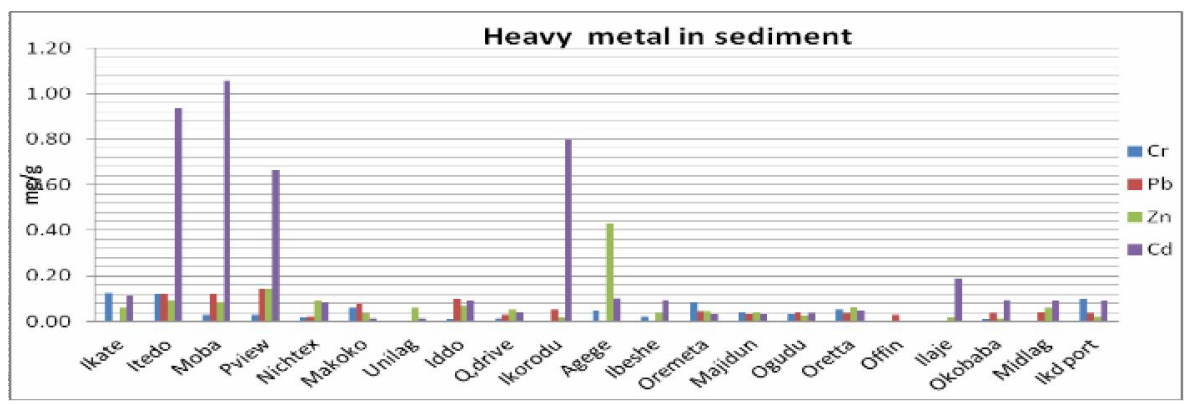

Figure 2. Distributions of heavy metals in the Sediment.

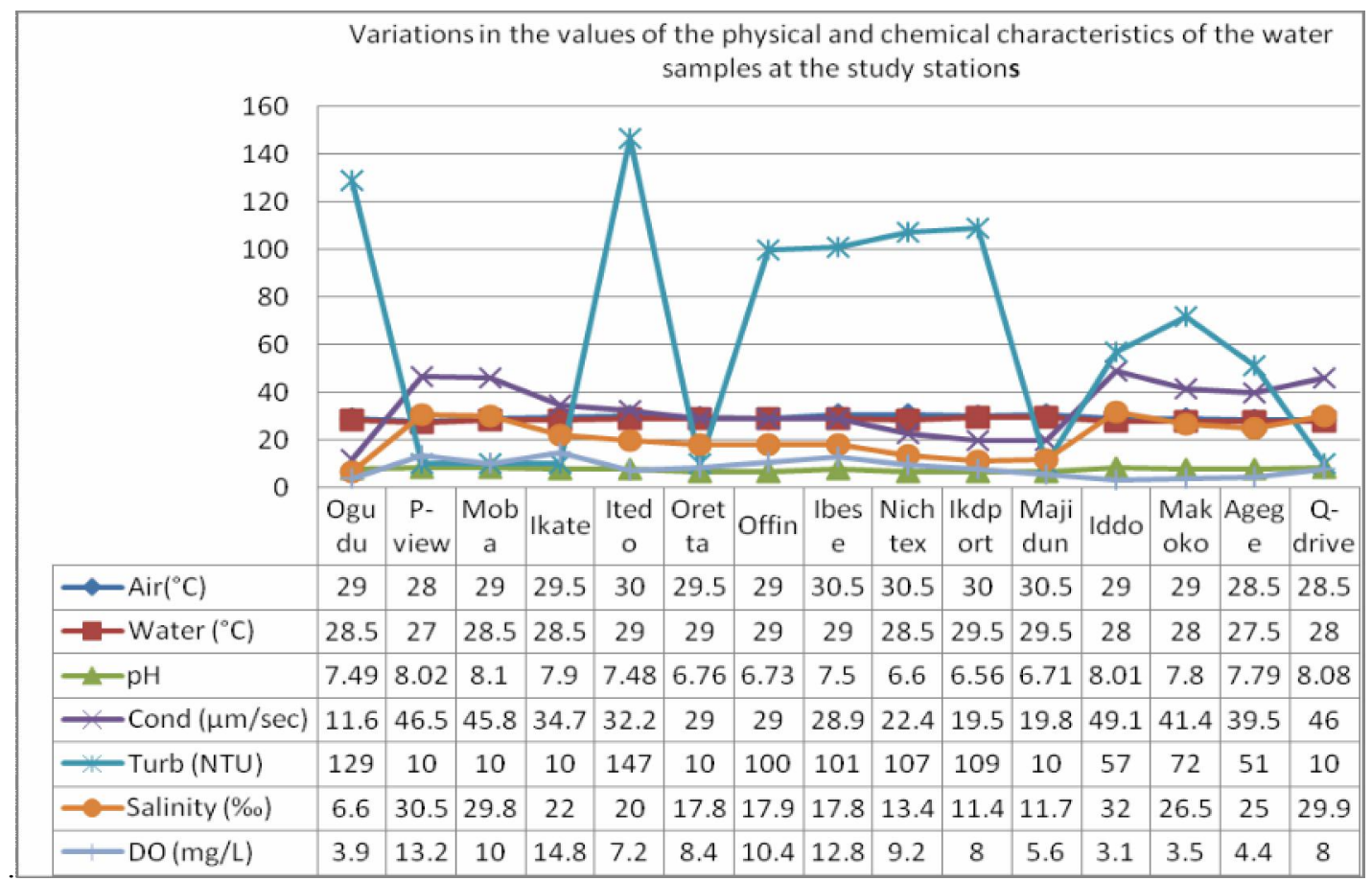

Figure 3. Distribution of the physicochemical parameters in the station 


\section{REFERENCE}

1. Ajayi, S.O, Osibanjo, O (1981). Water quality of some Nigeria Rivers. Environmental pollution. PP 87-95.

2. Federal Environmental Protection Agency (FEPA) 19986tygv, Guidelines and Standards for environmental Pollution control in Nigeria. Decree 58 of 1988, pp: 238.

3. Hill,M.B and Webb, J.E (1958).”The ecology of Lagos lagoon 11, The topography and physical features of Lagos Harbour and Lagos lagoon”.Phill Trans Roy.Soc.B.Vol 241.No 319-33.

4. Kjellstroem, T., 1986. Itai-itai disease. In: Friberg L, Elinder CG, Kjellstroem $\mathrm{T}$ and Nordberg GF (eds.) Cadmium and Health: A Toxicological and Epidemiological Appraisal Vol. 11, Effects of Response. CRC Press, Boca Raton, Florida, pp: 257-290.
5. Madejon,P., J.M. Murillo, T. Maranon, F. Cabrera and M.A. Soriano, 2003. Trace element and nutrient accumulation in sunflower plants two years after the Aznalcollar mine spill. Sci. Total Environ.,. 307(1-3): 239-257.

6. Oyewo, E.O.,K.N, Don Pedro (1998).Estimated Annual discharge rates of heavy metals from Industrial sources arround Lagos,a West African Coastal Metropolis.

7. Voutsinou-Taliadouri F., 1981. Metal Pollution in the Saronikos Gulf, Marine Pollution Bulletin, 12(5):163-168.

8. World health organisation (WHO), 2004. 